\author{
後藤 博三 ${ }^{11}$ 嶋田 豊1) 柴原 直利1) \\ 津田 昌樹2) 寺澤 捷年 ${ }^{1)}$
}

\title{
A Case of Chronic Osteomyelitis Successfully Treated with Kampo \\ Formula Keishi-mao-kakuhan-to
}

\author{
Hirozoh GOTOH ${ }^{1)}$ Yutaka SHIMADA ${ }^{1)}$ Naotoshi SHIBAHARA $^{1)}$ \\ Masaki TSUDA $^{2)}$ Katsutoshi TERASAWA ${ }^{1)}$
}

1) M. D. s, Department of Japaness Oriental (Kampo) Medicine, Toyama Medical and Pharmaceutical University, 2630, Sugitani, Toyama-shi, Toyama 930-01, Japan

2) Acupuncturist, Department of Japanese Oriental (Kampo) Medicine, Tonami General Hospital, Toyama

\begin{abstract}
A 27-year-old female had swelling, hotness and pain on her right clavicle. She was diagnosed as having chronic osteomyelitis and received bone curettement. However, even after this therapy, she occasionally suffered from recurrence of osteomyelitis. In the middle of July 1992, she was pregnant and had a low grade fever and pain from the right clavicle to the right upper arm. On she visited our department and was diagnosed as having deterioration of the chronic osteomyelitis with pregnancy, based on the symptoms and laboratory data. In Kampo diagnosis, she was in the initial stage of Yang diseases with ectodermal symptoms, since she had headache and fever with slight chills and her pulse was floating. She received Keishi-mao-kakuhan-to and acupuncture therapy. The therapy gradually improved the symptoms and laboratory data. The present case suggests that Oriental medicine is one approach to the treatment of chronic osteomyelitis. Furthermore, the fact that the present therapy was effective during pregnancy without any adverse effects supports the clinical usefulness of Oriental medicine, especially since administration of massive amounts of antibiotics or surgery is often not advisable for pregnant women.
\end{abstract}

Key words: Keishi-mao-kakuhan-to, osteomyelitis, acupuncture.

Nihon Toyo Igaku Zasshi (Japanese Journal of Oriental Medicine), 46, 279-283, 1995 (accepted 23 Feb, 1995)

1) 医, 富山医科薬科大学医学部和漢診療学講座, 富山， $=930-01$ 富山市杉谷 2630

2) 鍼, 市立砺波総合病院東洋医学科, 富山

[1995年 2 月23日受理] 


\section{緒 言}

慢性化膿性骨髄炎は, 各種抗生物質の使用が可 能となった今日に打いて子整形外科領域に打ける 難治性疾患の一つとされて牱り，本疾患の急性増 悪時には抗生物質大量投与や持続洗浄療法, 外科 的処置が必要となる1”。

今回我々は，妊娠を契機に増悪し，桂枝麻黄各 半湯が奏効した慢性化膿性骨髄炎の症例を経験し たので，文献的考察を加えて報告する。

\section{症 例}

[患 者] 27 歳, 主婦

[主 訴] 右鎖骨部痛

〔既往歷〕 20 歳, 左卵管水腫

[家族歴] 特記事項なし

[現病歴]1982年，右鎖骨部に腫脹，熱感，疼 痛が出現したために近医整形外科を受診し，慢性 化膿性骨髄炎との診断を受けた。罹患部の搔爬術 を施行されたが，その後も年に数回は同部に鈍痛 が生じ，抗生物質の内服により改善を得ていた。 1990年 4 月，再度同部に疼痛が出現したために某 大学整形外科を受診した。骨レントゲン・CT ス キャン・骨シンチグラム等により慢性骨䯣炎の再 燃と診断され，抗生物質及び消炎鎮痛剤の投与に より症状は改善傾向を示した。しかし，約 1 年間 の服薬にもかかわらず全快しないために自己中断
した。1992年 7 月中旬（妊娠 7 週）より右鎖骨部 から右上腕に鈍痛が出現し，また $37.5^{\circ} \mathrm{C}$ 前後の発 熱を伴ったため，同年 8 月に近医整形外科を受診 し，骨髄炎の再燃と診断された。妊娠を考慮し抗 生物質内服の保存的治療により経過観察すること となったが，抗生物質の長期内服による胎児に対 する影響が不安になり，また疼痛も改善が得られ なかったために，同年、に漢方薬治療を希 望し当科入院となった。

［現 症] 身長 $161.0 \mathrm{~cm}$ ，体重 $48.0 \mathrm{~kg}$ ，血圧 $132 / 72 \mathrm{mmHg}$ ，脈拍 $96 / \mathrm{min}$ 整，体温 $37.7^{\circ} \mathrm{C}$ ，眼 結膜に貧血，黄疸なし。表在リンパ節を触知せ ず。右鎖骨から胸鎖関節部に圧痛，腫脹，発赤を 認める。胸部聴打診上，心肺に異常所見なし。腹 部では肝脾腎を触知せず，圧痛なし。下腿浮腫を 認めず。

[検查成績】入院時検査成績を表 1 亿示す。白 血球数は $10,850 / \mu l$ と増加し, その分画では好中 球が76. $8 \%$ であった。赤沈 1 時間值は $63 \mathrm{~mm}$ と元 進し，また CRP も $3.5 \mathrm{mg} / \mathrm{d} \ell$ と炎症所見は陽性 であった。入院時の右鎖骨レントゲンでは，胸鎖 関節側に骨空洞（骨枢）形成像が認められた（図 1)。

[和漢診療学的所見] 自覚症状：易疲労感があ り，通常は寒がりであるが上半身に熱感がある。 また時に悪寒を自覚することがある。わずかに頭 重感が存在し，右鎖骨部に鈍痛と熱感がある。口

表 1 入院時検査成績

\begin{tabular}{cclclc}
\hline WBC & $10,850 / \mu \ell$ & TP & $7.4 \mathrm{~g} / \mathrm{d} \ell$ & $\mathrm{Na}$ & $138 \mathrm{mEq} / \ell$ \\
Neut & $76.8 \%$ & Alb & $4.0 \mathrm{~g} / \mathrm{d} \ell$ & $\mathrm{K}$ & $4.4 \mathrm{mEq} / \ell$ \\
Lym & $14.6 \%$ & LDH & $124 \mathrm{IU} / \ell$ & CI & $102 \mathrm{mEq} / \ell$ \\
Mono & $6.2 \%$ & GOT & $12 \mathrm{KU}$ & FBS & $92 \mathrm{mg} / \mathrm{d} \ell$ \\
Eos & $0.5 \%$ & GPT & $7 \mathrm{KU}$ & CRP & $3.5 \mathrm{mg} / \mathrm{d} \ell$ \\
Baso & $0.5 \%$ & $\gamma$-GTP & $16 \mathrm{IU} / \ell$ & ESR & $63 \mathrm{~mm} / \mathrm{hr}$ \\
RBC & $403 \times 10^{4} / \mu \ell$ & ALP & $6.1 \mathrm{KAU}$ & & \\
Hb & $12.4 \mathrm{~g} / \mathrm{d} \ell$ & T-Bil & $0.5 \mathrm{mg} / \mathrm{d} \ell$ & Urinalysis N. P. \\
Ht & $36.8 \%$ & T-Chol & $169 \mathrm{mg} / \mathrm{d} \ell$ & & \\
MCV & 91.4 & TG & $85 \mathrm{mg} / \mathrm{d} \ell$ & Stool & Occult blood $(-)$ \\
MCH & $30.9 \mathrm{pg}$ & BUN & $6 \mathrm{mg} / \mathrm{d} \ell$ & & \\
MCHC & $33.8 \%$ & Cr & $0.4 \mathrm{mg} / \mathrm{d} \ell$ & & \\
PLT & $38.2 \times 10^{4} / \mu \ell$ & UA & $2.2 \mathrm{mg} / \mathrm{d} \ell$ & & \\
\hline
\end{tabular}




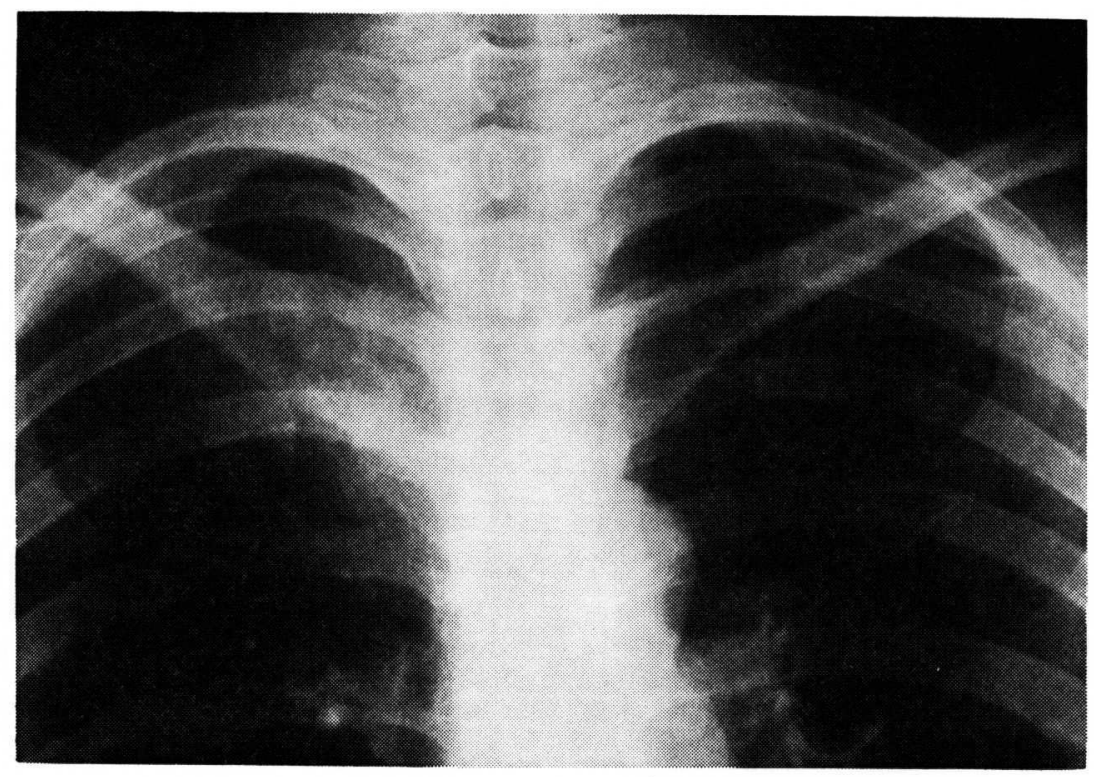

図 1 鎖骨部レントゲン写真。右鎖骨の胸鎖関節側に骨空洞（骨枢）を認める
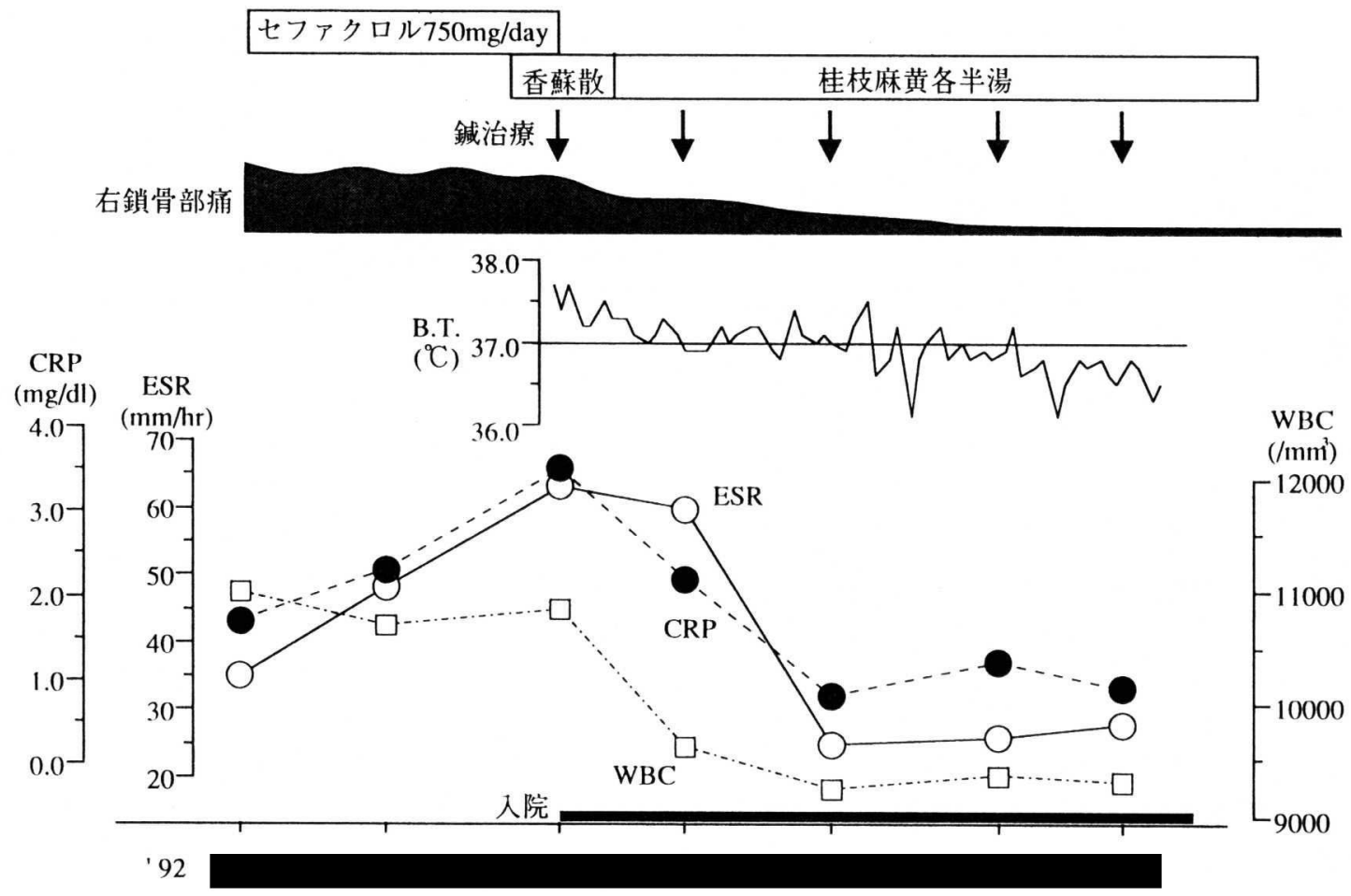

図 2 治療経過

渴はなく，食欲不振もない。二便に異常はない。 他覚所見：わずかに自汗傾向があり，右鎖骨部
に発赤と腫脹を認める。脈候は浮, やや大, やや 実である。舌候は舌質が淡白紅で，薄い乾燥傾向 
の微白苔を被っている。腹候で腹力はやや軟弱 で, 両側腹直筋が軽度緊張し, また臍上悸を認め る。

〔診 断] 西洋医学的には, 本症例を妊娠を契 機として急性増悪した右鎖骨慢性化膿性骨髄炎と 診断した。和漢診療学的には，微熱が持続してい たが，少陽・陽明期を示唆する所見に乏しく，ま た頭痛と軽い悪寒を伴う体熱感が存在し，脈が浮 であったことから病位は太陽病期にあるものと考 壳た。

[経過]入院後経過を図 2 亿示す。入院時の 炎症反応が入院前のものに比較して増貫していた ために，前医より継続投与されていたセファクロ ル (ケフラールR) $750 \mathrm{mg} / \mathrm{day}$ は無効之考光, 内 服を中止した。気秕様の症状や発熱, 脈浮を考慮 して外来で開始されていた香蘇散料を継続投与と し, 痛みの早期改善を目指し鍼治療を週 1 回併用 した。鍼治療は東方会方式の接触鍼法を用い，本 治法として曲泉穴に補法を，標治法として期門 穴・肝俞穴に補法を行なった。また局所の腫脹の 周囲に補鍼を，腫脹部と肩背部の気凿を呈した部 分に散鍼を行なった。鍼は $40 \mathrm{~mm}, 18$ 号の金鍼

（青木実意製，長柄鍼）を用いた。鍼治療により 疼痛は若干の改善が得られた。しかし，発熱は持 続した。そこで，「熱多く寒少なし」，「自汗傾 向」,「口渴なし」といら症候に注目し，第 4 病日 より桂枝麻黄各半湯に転方した。な特，妊娠を考 慮して処方内容は通常成人量に比較して半量で投 与した。転方後, 発赤や熱感については徐々に改 善を示し，また疼痛に対しても軽減が得られた。 検查所見では, 入院 2 週後には白血球数 $9,250 /$ $\mu \ell$ 赤沈 1 時間值 $25 \mathrm{~mm}, \mathrm{CRP} 0.8 \mathrm{mg} / \mathrm{d} \ell$ と改善 した。経過が良好であったため，同年 9 月 24 日退 院となった。退院時には右鎖骨部の腫脹は残存し ていたが, 局所の発赤, 熱感, 疼痛はほぼ消失し た。退院後も経過は順調で, 1993年 3 月 3 日に無 事女児を出産した。

\section{考 察}

慢性化膿性骨䯣炎のなかでも，鎖骨骨䯣炎は原 因不明の場合が多く，成人に好発し，また本症例
と同様に右側罹患例が多いとされている。発症は 緩徐で，発症当初から慢性の経過をたどる例が多 く, 手術所見でも膿瘍や肉芽を発見でさない症例 が少なくない。手術療法として病巣廓清術および 切除術が施行されるが，その治療成績は比較的不 良であり, 再発率が高く整形外科的にも難治性の 疾患とされている12)。本症例は既に右鎖骨部の 骨レントゲン・CT スキャン・骨シンチグラムの 集積像により慢性化膿性骨䯣炎之診断されて特 り, 入院時は同部に発赤, 腫脹, 熱感, 疼痛が存 在し，炎症反応が陽性を示したことから急性増悪 期にあると診断した。本症例の経過より，抗生物 質の内服中止後に桂枝麻黄各半湯と鍼治療を併用 し, 症状及び検查成績の改善が得られていること から, 本症例には桂枝麻黄各半湯と鍼治療の併用 が奏効したものと考える。

桂枝麻黄各半湯は傷寒論の太陽病編に記載され ている方剤であり，その条文には「太陽病，之ヨ 得テ八九日, 虐状ノ如ク, 発熱悪寒シ, 熱多ク寒 少ナク, 其ノ人嘔セズ, 清便自ヅカラ可ナラント 欲シ, 一日二三度発ス, (中略) 其ノ少シク汗出 ズルヨ得ル能ワザル 以以テ, 身必ズ痒シ, 桂枝麻 黄各半湯二宜シ。」とある3 ${ }^{3)}$ 。本症例では, 通常 は寒がりであるにもかかわらず入院時には上半身 に熱感があり，時に悪寒を自覚し，またわずかで はあるが頭重感が存在した。脈が浮, やや実で, 熱候を伴っていたことから, 病位は太陽病期位に あると診断し，自汗傾向があり，口渴がないこと を目標に桂枝麻黄各半湯を投与したものである。 本症例では, 慢性化膿性骨髄炎の発症から既に10 年が経過して和り，また今回の増悪後も既に 1 カ 月が経過している。太陽病は一般に疾病の初発の 時に見られる病態であるが，本症例のように慢性 感染症の急性増悪に際し現われることもある。藤 平4) は桂枝麻黄各半湯証を遷延型太陽病という言 葉で表現しており，さらに進んだ少陽病期には表 的少陽と裏的少陽があり，この表的少陽に極めて 近い状態に桂枝麻黄各半湯は位置しているとして いる。

本症例は, 慢性骨髄炎が妊娠という生体側の要 因により急性増悪したものであるが，抗生物質の 
内服のためか排膿するまでの増悪は示さずに，骨 䯣内でくすぶった状態にあり，そのために遷延型 太陽病という状態を呈して桂枝麻黄各半湯が奏効 したものと考觉る。

慢性化膿性骨髄炎に対する東洋医学的治療の報 告は少なく，代田 ${ }^{5)}$ と池田 ${ }^{6)}$ が大腿骨の骨髄炎の 治験例を，高橋》) が多発性の骨䯣骨膜炎の治験例 を報告している。また，荒度 ${ }^{8}$ は本症例同様鍼治 療を併用した骨䯣炎の治験例を報告している。本 症例を含めこれらの症例から遷延化した本症に対 しては，東洋医学的治療が有用であることが示唆 される。さらに，抗生物質の大量投与や外科的治 療の適応となりにくい妊婦に対して効果を呈した ことは，和漢薬治療の臨床上の有用性を示したと 考えられる。な沶，本症例については完治に至る までの慎重な経過観察が必要であり, 現在も加療 中である。

付記 本症例に打ける使用方剂の薬味構成, 分量, および産地は次に示すと括りである。 桂枝麻黄各半湯 :
桂枝 $2.5 \mathrm{~g}$ (広西省), 杏仁 $1.75 \mathrm{~g}$ (天津), 麻黄 $1.5 \mathrm{~g}$ (甘肃省), 大東 $1.5 \mathrm{~g}$ (山東省), 茄薬 $1.5 \mathrm{~g}$ (奈良県), 甘草 $1.5 \mathrm{~g}$ (内蒙古), 生姜 $0.5 \mathrm{~g}$ (雲南省)

香蘇散料 :

香附子 $4.0 \mathrm{~g}$ (北朝), 蘇葉 $2.0 \mathrm{~g}$ (広東省), 陳皮 2.0 $\mathrm{g}$ (日本), 甘草 $1.5 \mathrm{~g}$ (内蒙古), 生姜 $0.5 \mathrm{~g}$ (雲南省)

\section{文 献}

1) 倉田和夫 : 扁平・短骨の骨髓炎, 整形外科 $\mathrm{MO}$ OK, 40, No.21, 1982

2 ) 若山日名夫ほか：鎖骨骨髓炎の 1 例, 整形外科, $14 ; 214,1963$

3) 小倉重成：傷寒論解釈，医道の日本社，48，1991

4) 藤平 健: 桂枝麻黄各半湯の臨床応用, 日本東洋 医学雑誌, 35巻 2 号, 39 46, 1984

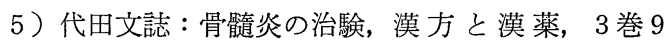
号, 67, 1936

6) 池田千寿: 慢性化膿性骨髓炎の治験例, 漢方々漢 薬, 5 巻 8 号, 66, 1938

7) 高橋道史 : 最近経験した慢性疾患の数々, 漢方の 臨床, 15 巻 8 号, 486, 1968

8 ）浅野正義：荒木先生の治験 4 , 活, 35 巻 8 号, 5 , 1993

要旨 症例は27歳の女性, 1982年に右鎖骨部に腫脹, 熱感, 疼痛が出現し, 慢性化膿性骨䯣 炎と診断され搔爬術を施行された。その後も再燃，寬解を繰り返し，1992年 7 月中旬，妊娠後 に右鎖骨部から上腕の鈍痛及び微熱が出現し，同年—当科入院。身体所見，検查成績 より妊娠を契機として増悪した右鎖骨慢性化膿性骨髄炎と診断した。和漢診療学的には，頭痛 と軽い悪寒を伴う体熱感があり，脈が浮であったことから，病位は太陽病期にあると考えた。 そこで，桂枝麻黄各半湯を投与し，また鍼治療を併用したところ，症状は徐々に軽減し，検查 成績にも改善が得られた。本症例は, 慢性化膿性骨䯣炎遷延例に対して東洋医学的治療が有用 であることを示唆している。さらに，抗生物質の大量投与や外科的治療の適応となりにくい妊 婦に対して効果を呈したことは，和漢薬治療の臨床上の有用性を示したと考号れる。

キーワード : 桂枝麻黄各半湯, 慢性化膿性骨髄炎, 鍼治療 